\title{
Spirit of Capitalism and Conspicuous Consumption with Social Status in a Neoclassical Growth Trade Model
}

\author{
Wei-Bin Zhang \\ College of International of Management, Ritusmeikan Asia Pacific University \\ 1-1 Jumonjibaru, Beppu-shi, Oita Ken, PO Box 874-8577, Japan \\ Tel: 81-977-73-9787Ｅ-mail: wbz1@apu.ac.jp
}

Received: December 1, 2015 Accepted: December 20, 2015

doi:10.5296/ber.v6i1.8652 URL: http://dx.doi.org/10.5296/ber.v6i1.8652

\begin{abstract}
This study deals with dynamic interactions among social status, conspicuous consumption, spirit of capitalism, global growth, trade patterns, and inequalities in income and wealth between countries. The paper constructs a multi-country growth model with endogenous physical capital, wealth accumulation and social status. The modelling of social status is influenced by the ideas related to economic growth and social status in the literature of economic growth. This study analyzes the role of conspicuous consumption by assuming that social status is enhanced by more consumption and the role of the spirit of capitalism (of some goods) by assuming that social status is enhanced by more wealth. The global economic system consists of any number of countries and each country has one capital goods sector and one consumer goods sector. This study applies an alternative utility function proposed by Zhang to analyze household behavior. The countries differ in preferences, spirits of capitalisms, and productivities. We show that the dynamics of $J$-country world economy is described by $J$ differential equations. We simulate the motion of the model with three countries and carry out comparative dynamic analysis with regard to some parameters.
\end{abstract}

Keywords: Trade pattern; Global economic growth, Spirit of capitalism, Conspicuous consumption, Social status, Inequality in income and wealth

\section{Introduction}

There are different studies on the role of conspicuous consumption, social status and spirit of capitalism in economic growth. In his well-known The Theory of the Leisure Class, Veblen (1899) studied economic consequences of conspicuous consumption and social status. Veblen strongly argued that people are interested in pursuing conspicuous consumption as it signals wealth and social status. Duesenberry (1949) points out that people may try to improve social 
status by imitating the consumption standard of the social or classes above them. In a recent study by Rege (2008), it is argued that people is concerned with social status because it serves a signal of non-observable abilities. According to Rege (2008: 240), "By investing in social status a person can thus improve his chance of engaging in a complementary interaction with a high ability person. The idea that status can serve as a signal of abilities is not new and has been captured in several models. It has, for example, been demonstrated that workers can signal their ability to employers by undertaking some seemingly irrelevant but costly activity interpreted as status consumption (Frank, 1985a) or social culture (Fang, 2001) and that people can "burn money" on fashions to signal abilities in a "dating game" ... ." It is argued that the introduction of social status makes traditional growth models more robust in explaining economic growth processes (see also, Cole et al., 1992; Konrad, 1992; Fershtman et al., 1996; Rauscher, 1997). Although there are some formal models about endogenous social status and economic growth, issues related to possible effects of endogenous social status are seldom examined in formal economic growth theory with international trade. It is important to take account of social status in modelling global economic growth. As different economies have different cultures and attitudes to social status, the introduction of social status into formal trade theory enables theoretical economists to comprehensively discuss differences in global growth and income and wealth distribution due to cultural and institutional differences.

The purpose of this study is concerned with social status and global growth with national inequalities in income and wealth. The way that social status are integrated into our trade model is influenced by the literature that studies the macroeconomic effects of consumers' wealth-induced preferences for social status. In this literature social status is considered as functions of private wealth within neoclassical growth models (Zou, 1994, 1995; Bakshi and Chen, 1996; Chang, 2006; Chang and Tsai, 2003; Corneo and Jeanne, 2001; Chang, et al. 2004; Clemens, 2004; Fisher and Hof, 2005; Chen and Guo, 2009, 2011). We introduce this idea to a multi-country growth model with endogenous physical capital and wealth accumulation. This study analyzes the role of conspicuous consumption by assuming that social status is enhanced by more consumption and the role of the spirit of capitalism (of some goods) by assuming that social status is enhanced by more wealth. The study analyzes not only inequalities in income, wealth and economic structures between (any number of) countries, but also differences in preferences and social status. The economic system is built on the basis of the Solow model, the Uzawa two-sector model, and the Oniki-Uzawa trade model. The first formal trade model with genuine dynamic analysis is proposed by Oniki and Uzawa (1965). Deardorff and Hanson (1978) propose a two country trade mode with different saving rates across countries. There are some other growth models with international trade (e.g., Brecher et al., 2002; Nishimura and Shimomura, 2002; Ono and Shibata, 2005). But none of these models contain social status. As far as capital accumulation and trade pattern determination are concerned, our study is influenced by the Oniki-Uzawa framework, even though we extend the Oniki-Uzawa model to include endogenous social status. We also deviate from the traditional approach in modeling behavior of households. This study applies an alternative approach to consumer behavior by Zhang (1993). The model in this study is a further development of the growth models by Zhang (1994, 2012, 2015). Zhang's previous models don't include social status and preference change. The paper is organized as follows. Section 2 develops the growth model of wealth and income 
distribution among heterogeneous households with endogenous social status. Section 3 examines the dynamic properties of the model and simulates the model with three groups. Section 4 carries out comparative dynamic analysis. Section 5 concludes the study.

\section{The Multi-country Trade Growth Model with Social Status}

The world economy consists of multiple countries, indexed by $j=1, \ldots, J$. Each country has a fixed population, $N_{j}, \quad(j=1, \ldots, J)$. Following Uzawa's analytical framework (Uzawa, 1961), we consider that each country has two sectors: one capital goods sector and one consumer goods sector. In describing the production sectors, we follow the neoclassical growth theory (e.g., Burmeister and Dobell, 1970; Azariadis, 1993; Barro and Sala-i-Martin, 1995). With regard to determination of international trade, this study is influenced by the Oniki-Uzawa trade model. It is assumed that all the countries produce homogenous capital goods. As reviewed by Ikeda and Ono (1992), most of trade models with endogenous capital is structured like Oniki-Uzawa trade model and its various extensions with one capital goods. Each country's consumer goods (and service) sector produces goods and services which are not tradable in the international markets. Households own assets of the economy and distribute their incomes to consume and save. Production sectors use capital and labor. Exchanges take place in perfectly competitive markets. Production sectors sell their product to households or to other sectors and households sell their labor and assets to production sectors. Factor markets work well; factors are inelastically supplied and the available factors are fully utilized at every moment. Saving is undertaken only by households, which implies that all earnings of firms are distributed in the form of payments to factors of production. Let prices be measured in terms of the capital goods and the price of the capital goods be unit. We denote the wage and interest rates by $w_{j}(t)$ and $r_{j}(t)$, respectively, in the $j$ th country. In the free trade system, the interest rate is identical throughout the world economy, i.e., $r(t)=r_{j}(t)$. Capital depreciates at a constant exponential rate $\delta_{k j}$, being independent of the manner of use. Let $p_{j}(t)$ denote the price of consumer goods in country $j$. We use subscript index, $i$ and $s$ to stand for capital goods sector and consumer goods sector, respectively. We use $N_{j m}(t)$ and $K_{j m}(t)$ to stand for the labor force and capital stocks employed by sector $m$ in country $j \cdot$ Let $_{j m}(t)$ stand for the output level of sector $m$ in country $j$.

\section{The capital goods sectors}

We assume that production of capital goods is to combine labor force and physical capital 


\section{Macrothink}

with constant technology. The production functions are specified as follows

$$
F_{j i}(t)=A_{j i} K_{j i}^{\alpha_{j i}}(t) N_{j i}^{\beta_{j i}}(t), A_{j i}, \alpha_{j i}, \beta_{j i}>0, \alpha_{j i}+\beta_{j i}=1,
$$

where $A_{j i}, \alpha_{j i}$, and $\beta_{j i}$ are positive parameters. The marginal conditions of the capital goods sectors are given by

$$
r(t)+\delta_{k j}=\frac{\alpha_{j i} F_{j i}(t)}{K_{j i}(t)}, w_{j}(t)=\frac{\beta_{j i} F_{j i}(t)}{N_{j i}(t)} .
$$

\section{The consumer goods sectors}

The production functions of the consumer goods sector are

$$
F_{j s}(t)=A_{j s} K_{j s}^{\alpha_{j s}}(t) N_{j s}^{\beta_{j s}}(t), \alpha_{j s}+\beta_{j s}=1, \alpha_{j s}, \beta_{j s}>0
$$

where $A_{j s}, \alpha_{j s}$, and $\beta_{j s}$ are the technological parameters of the consumer goods sector. The marginal conditions are

$$
r(t)+\delta_{j k}=\frac{\alpha_{j s} p_{j}(t) F_{j s}(t)}{K_{j s}(t)}, w_{j}(t)=\frac{\beta_{j s} p_{j}(t) F_{j s}(t)}{N_{j s}(t)} .
$$

\section{Current income and disposable income}

In this study, we use an alternative approach to modeling behavior of households proposed by Zhang (1993). Zhang $(2005,2009)$ applies this function to different economic problems and extensively discusses its relations to and differences with the traditional approaches to household behavior in economic theory. Let $\bar{k}_{j}(t)$ stand for per capita wealth of country $j$. We have $\bar{k}_{j}(t)=\bar{K}_{j}(t) / N_{j}$, where $\bar{K}_{j}(t)$ is the total wealth owned by country $j$. Per capita current income from the interest payment $r(t) \bar{k}_{j}(t)$, and the wage payment $w_{j}(t)$, is

$$
y_{j}(t)=r(t) \bar{k}_{j}(t)+w_{j}(t) .
$$

The per capita disposable income is the sum of the current disposable income and the value of wealth. That is

$$
\hat{y}_{j}(t)=y_{j}(t)+\bar{k}_{j}(t)
$$

\section{Description of social status}




\section{Mll Macrothink}

Business and Economic Research

ISSN 2162-4860

2016, Vol. 6, No. 1

A unique feature of this study is that we introduce social status and its effects on human behavior in a multi-country growth model with endogenous capital and economic structure. Although this study uses a different approach from the traditional growth models with social status, it is important to show how this study is influenced by the approaches to social status in formal economic theory. First, we consider a study by Chen and Guo (2009). By considering social status as a function of wealth, they assume that each household provides fixed labor supply and maximizes its lifetime utility $U$ as follows

$$
U=\int_{0}^{\infty}\left[\frac{c^{1-\sigma}(t)-1}{1-\sigma}+\beta \frac{k^{1-\sigma}(t)-1}{1-\sigma}\right] e^{\rho t} d t
$$

where $c(t)$ and $k(t)$, are respectively the household's consumption and capital stock, $\rho$

is the time discount rate, and $\beta$ measures the degree for the spirit of capitalism. It should be noted that Kurz (1968) first uses both consumption flows and capital stocks as components of utility functions. Zhou $(1994,1995)$ uses this form of utility functions, assuming that the household derives utilities from social status which is represented by the level of capital ownership. This study also uses the idea that social status is represented by the level of capital ownership. Another study by Chen and Guo (2011) investigates the effects of relative wealth-induced preferences for social status on the equilibrium growth in a standard one-sector AK model. The model predicts that there is a positive output-growth effect in response to changes of the strength for social status. The utility is specified as follows

$$
U=\int_{0}^{\infty} \frac{\left[c(t)(k(t) / K(t))^{\beta}\right]^{1-\sigma}-1}{1-\sigma} e^{-\rho t} d t .
$$

The household is assumed to derive utilities from the wealth-based social status which is represented by its physical-capital ownership $k(t)$ relative to the economy-wide level of physical capital stock $K(t)$. They interpret $\beta>0$ as the degree of the spirit of capitalism. Corneo and Jeanne (1999) use the following utility function

$$
U=\int_{0}^{\infty}[u(c(t))+v(t)] e^{\rho t} d t
$$

where $v(t)$ is a variable called an individual's social esteem.

Inspirited by the literature on economic growth with social status, this study specifies the social status of the representative household in country $j$ as functions of wealth as follows 


$$
\omega_{j}\left(\left(\bar{k}_{j}(t)\right)\right)=\omega_{j 0}+\omega_{j L} \bar{k}_{j}(t)
$$

where $\omega_{j 0}$ and $\omega_{j L}$ positive parameters. The specified form implies that the social status is positively related to the household's wealth. As in Chen and Guo (2009), we may interpret $\omega_{j L}$ as the degree for the spirit of capitalism. This is a simplified form of possible social status functions as social status can be dependent on many other variables such as education, human capital, family heritage, human networks with celebrities, relative richness in the same group position, and the like. In particular, we should consider social status as functions of relative richness within each country and between countries. We accept the above functional forms for convenience of analysis.

\section{Budget and utility function}

The disposable income is used for saving and consumption. The representative household in country $j$ would distribute the total available budget between savings $s_{j}(t)$ and consumer goods $c_{j}(t)$. The budget constraint is

$$
p_{j}(t) c_{j}(t)+s_{j}(t)=\hat{y}_{j}(t)
$$

In our model, at each point in time, consumers have two variables to decide. Following Zhang (2009), we assume that the utility level $U_{j}(t)$ is dependent on $c_{j}(t)$ and $s_{j}(t)$ as follows

$$
U_{j}(t)=c_{j}^{\xi_{j 0}\left(\omega_{j}(t)\right)}(t) s_{j}^{\lambda_{j 0}\left(\omega_{j}(t)\right)}(t), \quad \xi_{j 0}\left(\omega_{j}(t)\right), \lambda_{j 0}\left(\omega_{j}(t)\right)>0,
$$

where $\xi_{j 0}\left(\omega_{j}(t)\right)$ is the propensity to consume consumer goods and $\lambda_{j 0}\left(\omega_{j}(t)\right)$ the propensity to save. Different from the traditional approaches where social status directly enter utility functions, this study assumes that social status affects behavior of households through influencing the propensities to consume and to save. It is through conducting conspicuous consumption (which increases the propensity to consume some kinds of services or commodities) or enhancing spirit of capitalism (which enhances the propensity to save) that social status affects households' behavior. In reality some goods are used for conspicuous consumption and some are not. As we use the highly aggregated consumer goods to represent different goods and services, our specified utility function does not explain which goods are used to exhibit conspicuous consumption.

\section{Social status and propensities to save and to consume}

Rather than using capital stock such as wealth as a decision variable, we consider that it is 


\section{Macrothink}

through affecting the propensities to consume and to save that social status affect growth and inequality. This study assumes the propensities to consume and to save to be related to social status in the following way

$$
\xi_{j 0}\left(\omega_{j}(t)\right)=\bar{\xi}_{j 0}+\tilde{\xi}_{j 0} \omega_{j}(t), \quad \lambda_{j 0}\left(\omega_{j}(t)\right)=\bar{\lambda}_{j 0}+\tilde{\lambda}_{j 0} \omega_{j}(t),
$$

where $\bar{\xi}_{j 0}$ and $\bar{\lambda}_{j 0}$ are positive parameters, and $\tilde{\xi}_{j 0}$ and $\tilde{\lambda}_{j 0}$ are parameters which may be either positive, zero, or negative. The propensity to consume may be enhanced by social status, for instance, through the so-called conspicuous consumption. The propensity to save is influenced by social status as more wealth tends to enhance social status. In our approach we consider the spirit of capitalism affects the propensity to save. Although social status may interact with propensities through many channels in nonlinear relations, this study accepts the above linear form for convenience of analysis.

\section{Optimal household behavior}

Maximizing the utility subject to (8) yields

$$
p(t) c_{j}(t)=\xi_{j}\left(\left(\bar{k}_{j}(t)\right)\right) \hat{y}_{j}(t), \quad s_{j}(t)=\lambda_{j}\left(\left(\bar{k}_{j}(t)\right)\right) \hat{y}_{j}(t),
$$

where

$$
\begin{aligned}
& \xi_{j}\left(\left(\bar{k}_{j}(t)\right)\right) \equiv \rho_{j}\left(\left(\bar{k}_{j}(t)\right)\right) \xi_{j 0}\left(\left(\bar{k}_{j}(t)\right)\right), \quad \lambda_{j}\left(\left(\bar{k}_{j}(t)\right)\right) \equiv \rho_{j}\left(\left(\bar{k}_{j}(t)\right)\right) \lambda_{j 0}\left(\left(\bar{k}_{j}(t)\right)\right), \\
& \rho_{j}\left(\left(\bar{k}_{j}(t)\right)\right) \equiv \frac{1}{\left.\xi_{j 0}\left(\left(\bar{k}_{j}(t)\right)\right)+\lambda_{j 0}\left(\left(\bar{k}_{j}(t)\right)\right)\right)} .
\end{aligned}
$$

\section{Wealth accumulation}

According to the definition of $s_{j}(t)$, the change in the household's wealth is given by

$$
\dot{\bar{k}}_{j}(t)=s_{j}(t)-\bar{k}_{j}(t)
$$

This equation simply states that the change in wealth is equal to the saving minus the dissaving.

\section{Demand and supply}

We use $K(t)$ to stand for the capital stocks of the world economy. The total capital stock employed by country $j, K_{j}(t)$, is allocated between the country's two sectors. Full employment of labor and capital implies

$$
K_{j i}(t)+K_{j s}(t)=K_{j}(t), \quad N_{j i}(t)+N_{j s}(t)=N_{j} .
$$




\section{Macrothink}

\section{Clearing conditions of the global capital markets}

The total capital stock employed by the world is equal to the wealth owned by the world. That is

$$
K(t)=\sum_{j=1}^{J} K_{j}(t)=\sum_{j=1}^{J} \bar{K}_{j}(t)=\sum_{j=1}^{J} \bar{k}_{j}(t) N_{j},
$$

where $\bar{K}_{j}(t)$ is the wealth owned by country $j$.

\section{Demand and supply}

The clearing condition for consumer goods in each country is

$$
c_{j}(t) N_{j}=F_{j s}(t), \quad j=1, \ldots, J .
$$

\section{Trade balances}

The world production is equal to the world net savings. That is

$$
S(t)-K(t)+\sum_{j=1}^{J} \delta_{j k} K_{j}(t)=F(t)
$$

where

$$
S(t) \equiv \sum_{j=1}^{J} s_{j}(t) N_{j}, \quad F(t) \equiv \sum_{j=1}^{J} F_{j}(t)
$$

We introduce trade balances of the economies as follows

$$
B_{j}(t)=\left(\bar{K}_{j}(t)-K_{j}(t)\right) r(t)
$$

When $B_{j}(t)$ is positive (negative), we say that country $j$ is in trade surplus (deficit). When $B_{j}(t)$ is zero, country $j^{\prime} s$ trade is in balance.

We completed the model. Irrespective of the obvious strict assumptions in our model, from a structural point of view the model is quite general in the sense that some well-known models in economics can be considered as its special cases. For instance, our model is structurally similar to the neoclassical growth model by Solow (1956) and Uzawa (1961). Our model is also structurally similar to the Oniki-Uzawa trade model (Oniki and Uzawa, 1965). As mentioned before, our approach is influenced by some growth models in the literature of growth models with social status. 


\section{The Multi-country Trade Growth Model with Social Status}

The dynamic system consists of any (finite) number of national economies. The heterogeneity in households among countries implies that this dynamic system is nonlinear and highly dimensional. The following lemma shows that the dimension of the dynamical system is the same as the number of countries. We also provide a computational procedure for calculating all the variables at any point in time. Before stating the lemma, we introduce new variables $z_{j}(t)$ by

$$
z_{j}(t) \equiv \frac{r(t)+\delta_{j k}}{w_{j}(t)}, \quad j=1, \ldots, J
$$

\section{Lemma}

The dynamics of the world economy is governed by the following $J$ dimensional differential equations system with $z_{1}(t), \quad\left\{\bar{k}_{j}(t)\right\}$, where $\left\{\bar{k}_{j}(t)\right\} \equiv\left(\bar{k}_{2}(t), \cdots, \bar{k}_{J}(t)\right)$, as the variables

$$
\begin{gathered}
\dot{z}_{1}(t)=\Lambda_{1}\left(z_{1}(t),\left\{\bar{k}_{j}(t)\right\}\right), \\
\dot{\bar{k}}_{j}(t)=\Lambda_{j}\left(z_{1}(t),\left\{\bar{k}_{j}(t)\right\}\right), \quad j=2, \ldots, J,
\end{gathered}
$$

in which $\Lambda_{j}$ are unique functions of $z_{1}(t)$ and $\left\{\bar{k}_{j}(t)\right\}$ defined in the Appendix. For any given positive values of $z_{1}(t)$ and $\left\{\bar{k}_{j}(t)\right\}$, at any point in time, the other variables are uniquely determined by the following procedure: $r(t)$ and $w_{j}(t)$ by (A2) $\rightarrow z_{j}(t)$ by $(\mathrm{A} 3) \rightarrow \bar{k}_{1}(t)$ by $(\mathrm{A} 15) \rightarrow \xi_{j}(t)$ by $(\mathrm{A} 13) \rightarrow \lambda_{j}(t)=1-\xi_{j}(t) \rightarrow N_{j s}(t)$ by $(\mathrm{A} 7) \rightarrow$ $N_{j i}(t)$ by $(\mathrm{A} 8) \rightarrow \hat{y}_{j}(t)$ by $(\mathrm{A} 5) \rightarrow K_{j s}(t)$ and $K_{j i}(t)$ by $(\mathrm{A} 1) \rightarrow F_{j i}(t)$ and $F_{j s}(t)$ by the definitions $\rightarrow p_{j}(t)$ by (A4) $\rightarrow c_{j}(t)$ and $s_{j}(t)$ by $(13) \rightarrow \bar{K}_{j}(t)=\bar{k}_{j}(t) N_{j} \rightarrow$ $B_{j}(t)=\left(\bar{K}_{j}(t)-K_{j}(t)\right) r(t) \rightarrow K_{j}(t)=K_{j i}(t)+K_{j s}(t) \rightarrow K(t)=\sum_{j} \bar{k}_{j}(t) N_{j}$.

The lemma provides a computational procedure for illustrating the motion of the economic system with any number of countries. As it is difficult to interpret the analytical results, to study the properties of the system we simulate the model for a 3 -country economy. We specify the parameter values as follows 


$$
\begin{aligned}
\left(\begin{array}{l}
N_{1} \\
N_{2} \\
N_{3}
\end{array}\right)=\left(\begin{array}{l}
10 \\
20 \\
30
\end{array}\right),\left(\begin{array}{l}
A_{1 i} \\
A_{2 i} \\
A_{3 i}
\end{array}\right)=\left(\begin{array}{c}
1.7 \\
1 \\
0.8
\end{array}\right),\left(\begin{array}{l}
A_{1 s} \\
A_{2 s} \\
A_{3 s}
\end{array}\right)=\left(\begin{array}{l}
1.5 \\
0.9 \\
0.7
\end{array}\right),\left(\begin{array}{l}
\alpha_{1 i} \\
\alpha_{2 i} \\
\alpha_{3 i}
\end{array}\right)=\left(\begin{array}{l}
0.31 \\
0.31 \\
0.31
\end{array}\right),\left(\begin{array}{l}
\alpha_{1 s} \\
\alpha_{2 s} \\
\alpha_{3 s}
\end{array}\right)=\left(\begin{array}{l}
0.33 \\
0.33 \\
0.33
\end{array}\right), \\
\left(\begin{array}{l}
\omega_{10} \\
\omega_{20} \\
\omega_{30}
\end{array}\right)=\left(\begin{array}{l}
0.01 \\
0.01 \\
0.01
\end{array}\right),\left(\begin{array}{l}
\omega_{1 \mathrm{~L}} \\
\omega_{2 \mathrm{~L}} \\
\omega_{3 \mathrm{~L}}
\end{array}\right)=\left(\begin{array}{c}
0.01 \\
0.008 \\
0.005
\end{array}\right),\left(\begin{array}{l}
\bar{\lambda}_{10} \\
\bar{\lambda}_{20} \\
\vec{\lambda}_{30}
\end{array}\right)=\left(\begin{array}{c}
0.8 \\
0.75 \\
0.7
\end{array}\right),\left(\begin{array}{l}
\tilde{\lambda}_{10} \\
\tilde{\lambda}_{20} \\
\tilde{\lambda}_{30}
\end{array}\right)=\left(\begin{array}{l}
0.1 \\
0.1 \\
0.1
\end{array}\right),\left(\begin{array}{l}
\bar{\xi}_{10} \\
\bar{\xi}_{20} \\
\bar{\xi}_{30}
\end{array}\right)=\left(\begin{array}{c}
0.12 \\
0.18 \\
0.2
\end{array}\right), \\
\left(\begin{array}{l}
\tilde{\xi}_{10} \\
\tilde{\xi}_{20} \\
\tilde{\xi}_{30}
\end{array}\right)=\left(\begin{array}{l}
0.05 \\
0.05 \\
0.05
\end{array}\right),\left(\begin{array}{l}
\delta_{1 k} \\
\delta_{2 k} \\
\delta_{3 k}
\end{array}\right)=\left(\begin{array}{l}
0.05 \\
0.04 \\
0.04
\end{array}\right) .
\end{aligned}
$$

The population of country 3 is largest, while the population of country 2 is the next. The capital goods and consumer goods sector's total productivities in country 1 are highest, and the capital goods and consumer goods sector's total productivities in country are lowest. We specify the values of the parameters, $\alpha_{j}$, in the Cobb-Douglas productions for the capital goods and consumer goods sectors approximately equal to 0.3 (for instance, Miles and Scott, 2005; Abel et al., 2007). Also according to Bernanke and Gurkaynak (2001), the labor share is 0.65 . The depreciation rate of physical capital is specified about 0.05 . In the literature of economic growth physical depreciation rates are often fixed near 0.05. In their empirical studies Nadiri and Prucha (1993) estimate the depreciation rate of physical capital 0.059. It should be noted that there are different empirical results in estimation of depreciation rates of physical capital and knowledge (e.g., Nadiri and Prucha, 1993; Frau, 1997; Hall, 2007). The values of the parameters associated with the social status and preference change are small. We will examine how the system is affected as these parameters vary. We specify the initial conditions as follows

$$
z_{1}(0)=0.077, \bar{k}_{2}(0)=2.7, \bar{k}_{3}(0)=2 .
$$

The motion of the variables is plotted in Figure 1. In Figure 1, the global income is

$$
Y(t)=Y_{1}(t)+Y_{2}(t)+Y_{3}(t), Y_{j}(t)=F_{j i}(t)+p_{j}(t) F_{j s}(t)
$$

The global output is slightly changed and global wealth is reduced over time with the given initial conditions. Different sectors in different countries experience different paths of economic development due to wealth accumulation, international trade and social status dynamics. Some sectors produce less and use less inputs, while other sectors produce more and use more input factors. The rate of interest rises in association with falls in the global capital. The prices of services and wage rates in the three economies are changed slightly. 


\section{Macrothink}

The preferences, wealth and consumption levels of the households are also slightly changed in the three economies. Our simulation demonstrates persistent divergence in income and wealth between households in different countries. It should be noted that as much of the discussion of income convergence in the literature of economic growth and development is based on the insights from analyzing models of closed economies (Barro and Sala-i-Martin, 1995), the main streams in economics still lack proper analyses of issues related to global income and wealth convergence with a framework of international interactions. The reason for this is that there are few growth models with endogenous wealth and trade on the basis of microeconomic foundation. For instance, the Solow model of closed economies predicts that convergence in income levels among closed countries is achieved by faster accumulation of physical capital in the poor countries. Nevertheless, if poor countries are opened to trade, the convergence may be stopped. As shown in Figure 1, the countries will not experience convergence in per capita income, consumption and wealth in the long term as they are different in preferences and total productivities.
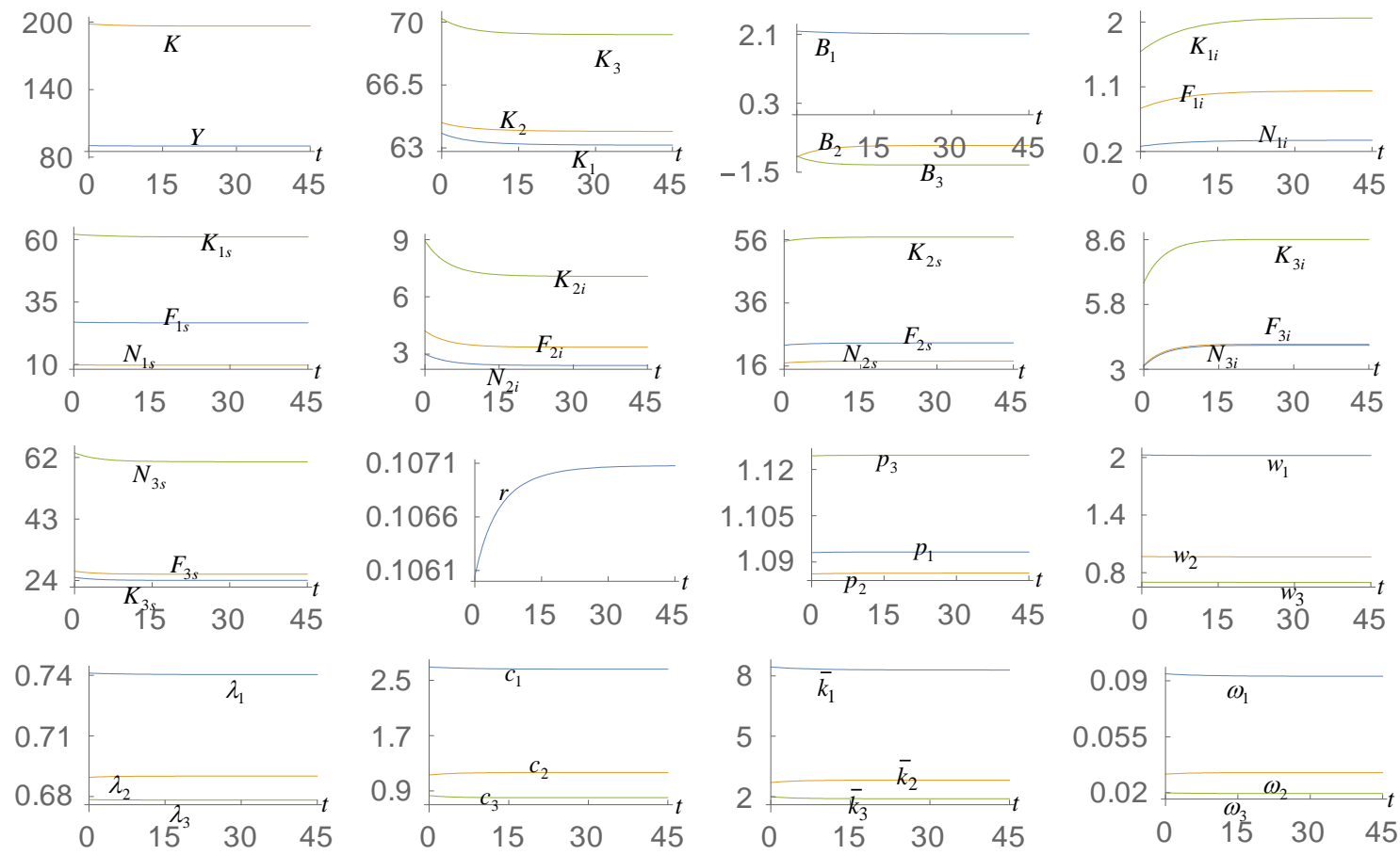

Figure 1. The Motion of the Economic System

We also simulate the model with other initial conditions. We notice that all the variables tend to become stationary over time with different initial conditions. This hints on that the system has a stable equilibrium point. We identify the following equilibrium point

$$
\begin{gathered}
Y=89.95, K=196.38, \quad r=0.107, \\
\left(\begin{array}{l}
Y_{1} \\
Y_{2} \\
Y_{3}
\end{array}\right)=\left(\begin{array}{l}
30.13 \\
28.69 \\
31.13
\end{array}\right),\left(\begin{array}{l}
\bar{K}_{1} \\
\bar{K}_{2} \\
\bar{K}_{3}
\end{array}\right)=\left(\begin{array}{l}
81.92 \\
56.43 \\
57.03
\end{array}\right),\left(\begin{array}{l}
K_{1} \\
K_{2} \\
K_{3}
\end{array}\right)=\left(\begin{array}{l}
63.16 \\
63.92 \\
69.30
\end{array}\right),\left(\begin{array}{l}
B_{1} \\
B_{2} \\
B_{3}
\end{array}\right)=\left(\begin{array}{c}
2.11 \\
-0.8 \\
-1.31
\end{array}\right),\left(\begin{array}{l}
p_{1} \\
p_{2} \\
p_{3}
\end{array}\right)=\left(\begin{array}{l}
1.093 \\
1.086 \\
1.125
\end{array}\right),
\end{gathered}
$$




$$
\begin{gathered}
\left(\begin{array}{l}
w_{1} \\
w_{2} \\
w_{3}
\end{array}\right)=\left(\begin{array}{l}
2.02 \\
0.97 \\
0.70
\end{array}\right),\left(\begin{array}{l}
F_{1 i} \\
F_{2 i} \\
F_{3 i}
\end{array}\right)=\left(\begin{array}{l}
1.04 \\
3.36 \\
4.09
\end{array}\right),\left(\begin{array}{l}
F_{1 s} \\
F_{2 s} \\
F_{3 s}
\end{array}\right)=\left(\begin{array}{c}
26.6 \\
23.32 \\
24.05
\end{array}\right),\left(\begin{array}{l}
N_{1 i} \\
N_{2 i} \\
N_{3 i}
\end{array}\right)=\left(\begin{array}{c}
0.36 \\
2.4 \\
4.04
\end{array}\right),\left(\begin{array}{l}
N_{1 s} \\
N_{2 s} \\
N_{3 s}
\end{array}\right)=\left(\begin{array}{c}
9.64 \\
17.6 \\
25.96
\end{array}\right), \\
\left(\begin{array}{l}
K_{1 i} \\
K_{2 i} \\
K_{3 i}
\end{array}\right)=\left(\begin{array}{l}
2.06 \\
7.08 \\
8.61
\end{array}\right),\left(\begin{array}{l}
K_{1 s} \\
K_{2 s} \\
K_{3 s}
\end{array}\right)=\left(\begin{array}{c}
61.1 \\
56.84 \\
60.69
\end{array}\right),\left(\begin{array}{l}
\omega_{1} \\
\omega_{2} \\
\omega_{3}
\end{array}\right)=\left(\begin{array}{l}
0.09 \\
0.03 \\
0.02
\end{array}\right),\left(\begin{array}{l}
\lambda_{1} \\
\lambda_{2} \\
\lambda_{3}
\end{array}\right)=\left(\begin{array}{l}
0.74 \\
0.69 \\
0.68
\end{array}\right),\left(\begin{array}{l}
\xi_{1} \\
\xi_{2} \\
\xi_{3}
\end{array}\right)=\left(\begin{array}{l}
0.26 \\
0.31 \\
0.32
\end{array}\right), \\
\left(\begin{array}{l}
\bar{k}_{1} \\
\bar{k}_{2} \\
\bar{k}_{3}
\end{array}\right)=\left(\begin{array}{l}
8.29 \\
2.82 \\
1.9
\end{array}\right),\left(\begin{array}{l}
c_{1} \\
c_{2} \\
c_{3}
\end{array}\right)=\left(\begin{array}{c}
2.66 \\
1.17 \\
0.8
\end{array}\right) .
\end{gathered}
$$

Due to their income and wealth differences in the long term, we call countries 1, 2, 3, respectively, as the rich, middle, and poor countries. Our main concern is how changes in attitudes toward social status and other parameters affect transitory paths and convergence of national economies. It is straightforward to calculate the three eigenvalues at the equilibrium point as follows: $-0.24,-0.22,-0.13$. The equilibrium point is stable. This conclusion is important as it guarantees that we can effectively carry out comparative dynamic analysis.

\section{Comparative Dynamic Analysis}

We simulated the motion of the dynamic system. It is important to ask questions such as how changes in one country's attitudes towards conditions will affect the global economy and environment of different countries. First, we introduce a variable $\bar{\Delta} x_{j}(t)$ which stands for the change rate of the variable, $x_{j}(t)$, in percentage due to changes in the parameter value.

\section{The poor country's spirit of capitalism being enhanced}

In this study by spirit of capitalism we narrowly mean the desire for accumulating more wealth. It is referred to the weight given to the social status in the propensity to save. We consider that the countries are different in their spirits of capitalism. It is important to examine how a country, like China or India, may affect the global economy when its spirit of capitalism is enhanced. Rich countries like Japan and Western European countries may weaken their spirits of capitalism when they have experienced stable and affluent environments. We now examine the effects of the following change in the parameter: $\omega_{3 L}: 0.005 \Rightarrow 0.01$. We interpret this change as that the poor country enhances its spirit of capitalism. The simulation result is plotted in Figure 2. As the poor country emphasizes stronger spirit of capitalism (through demonstrating wealth but not conducting conspicuous consumption), we see that the social status level of the poor is enhanced and its propensity to save (to consume) is augmented (subsided). The poor initially experiences falling in the household's consumption. As a consequence of raising wage and wealth, the poor has higher 
consumption level in the long term. Its higher spirit of capitalism enables the poor to consume more, to have more wealth and boast higher social status. From the figure we also see that the enhanced spirit of capitalism has a strong impact on the global economy as well. The global income and global wealth are augmented. The wage rates in the three economies are enhanced and the rate of interest is sunk in association with rising wealth. The prices of services fall slightly in all the national economies. The national incomes of and capital employed by all the three economies are increased. The poor country's trade balance is improved and the other two economies' trade balances are deteriorated. Different sectors are also affected differently. The capital inputs of the two sectors in both the rich and middle economies are increased. The capital input of the capital (service) goods sector in the poor economy is increased (reduced) initially and subsided (augmented) in the long term. Some of the labor force is shifted from the consumer goods sector to the capital goods sector in the rich and middle economies. In the poor economy some of the labor force is initially shifted from the consumer goods sector to the capital goods sector and in the long term some of the labor force is shifted from the capital goods sector to the consumer goods sector. The service outputs in the rich and middle economies are reduced. In the poor country the service output falls initially and rises in the long term. The capital goods outputs in the rich and middle economies are enhanced. In the poor country the capital goods output rises initially and falls in the long term. The social statuses of the rich and middle are slightly affected. The consumption and wealth levels of the middle economy are slightly affected. The consumption and wealth levels of the rich economy are slightly reduced. We see that the enhancement in the poor's spirit of capitalism lessens the inequality gaps between the rich and poor. It should be noted that in their research on interaction between pecuniary emulation and inequality, Corneo and Jeanne (1999: 1667) conclude: "On the one hand, the presence of pecuniary emulation tends to underscore the conventional view that equality has a positive impact on growth. A more equal distribution of wealth, by reducing the distance between the wealth levels of classes, makes pecuniary emulation easier for the poor. Hence, equality strengthens the incentive to accumulate for status reasons, and is beneficial for economic growth. This mechanism has already been put forward by Cole et al. (1992) and Fershtman et al. (1996), and is thoroughly investigated in our companion paper Corneo and Jeanne (1997a)." Our simulation implies the same phenomenon. 

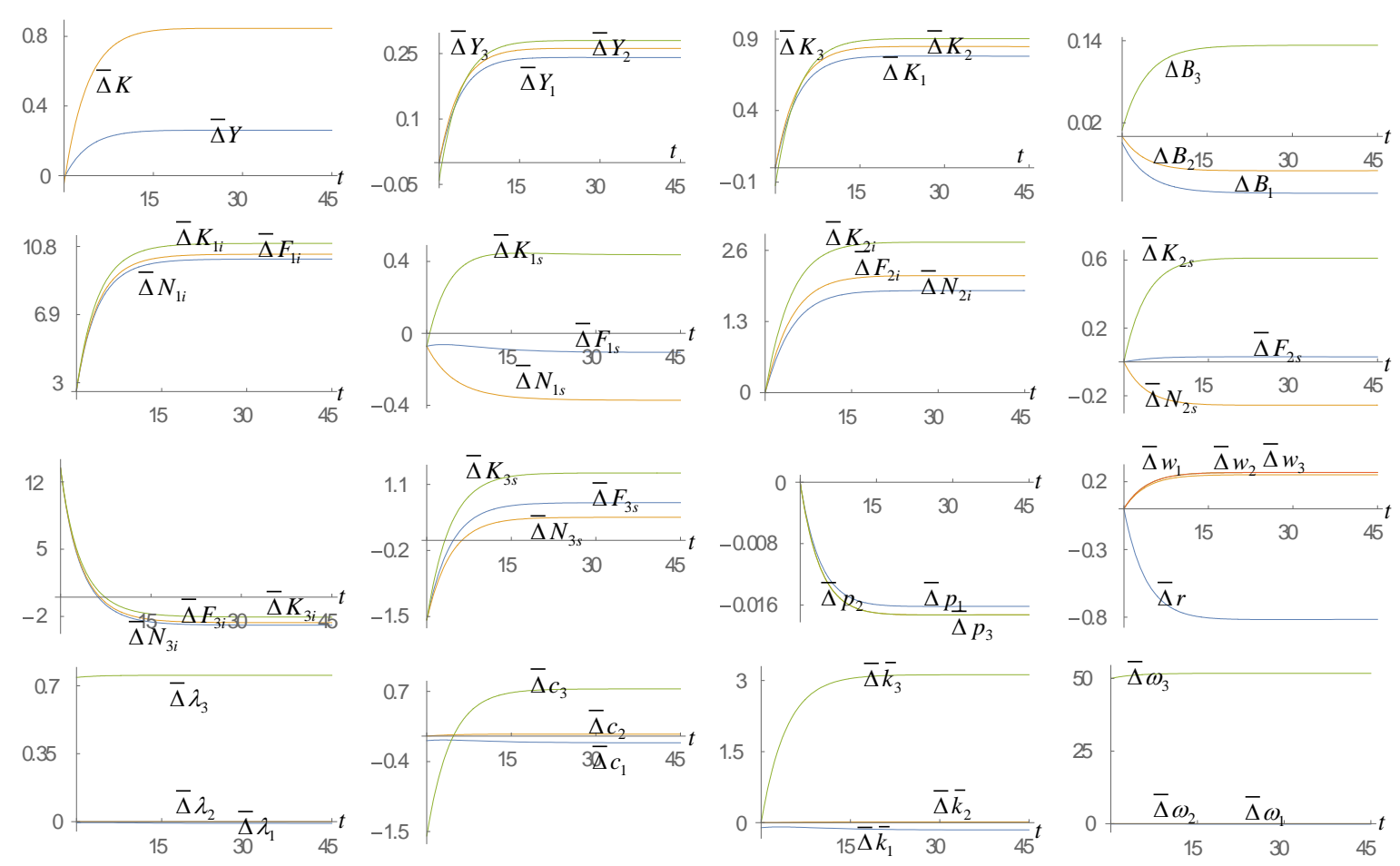

Figure 2. The Poor Country's Spirit of Capitalism Being Enhanced

\section{The poor country's conspicuous consumption being encouraged}

In this study by conspicuous consumption we narrowly mean show-off by consuming more consumer goods. Different from the spirit of capitalism, this desire for demonstrating social status by consuming more tends to increase the propensity to consume. It is specially referred to the weight given to social status in the propensity to consume. It is important to examine how a country, like China, may affect the global economy when it tends to display its wealth by more conspicuous consumer goods. We now examine the effects of the following change

in the parameter: $\tilde{\xi}_{30}: 0.05 \Rightarrow 0.055$. We interpret this change as that the poor country strengthens conspicuous consumption. The simulation result is plotted in Figure 3. The social status level of the poor is lowered and its propensity to save is reduced. The poor initially experiences rising in the household's consumption as a consequence of enhanced propensity to consume. As a consequence of lowering wage and losing wealth, the poor has higher consumption level in the long term irrespective of its increased propensity to consume. In the long term its higher propensity to consume makes the poor to consume less, to have less wealth and to suffer from dropped social status. From the figure we see that the global income and global wealth are reduced. The national incomes of all the countries are lowered. The wage rates in the three economies are dropped and the rate of interest is augmented in tandem with falling wealth. All the national economies use less capital inputs. The prices of services rise slightly in all the national economies. The poor country's trade balance is deteriorated and the other two economies' trade balances are improved. There are also economic structural changes in the three economies. The capital input of the capital (service) goods sector in the poor economy is reduced (increased) initially and raised (lowered) in the 
long term. Some of the labor force is shifted from the capital goods sector to the consumer goods sector in the rich and middle economies. In the poor economy some of the labor force is initially shifted from the capital goods sector to the consumer goods sector and in the long term some of the labor force is shifted from the consumer goods sector to the capital goods sector. The service outputs in the rich and middle economies are increased. In the poor country the service output rises initially and falls in the long term. The capital goods outputs in the rich and middle economies are reduced. In the poor country the capital goods output falls initially and rises in the long term. The social statuses of the rich and middle are increased. The consumption and wealth levels of the middle economy are slightly affected. The consumption and wealth levels of the rich economy are increased. We see that the encouraged conspicuous consumption of the poor reduces the global income and wealth and enlarges the inequality gaps between the rich and poor.
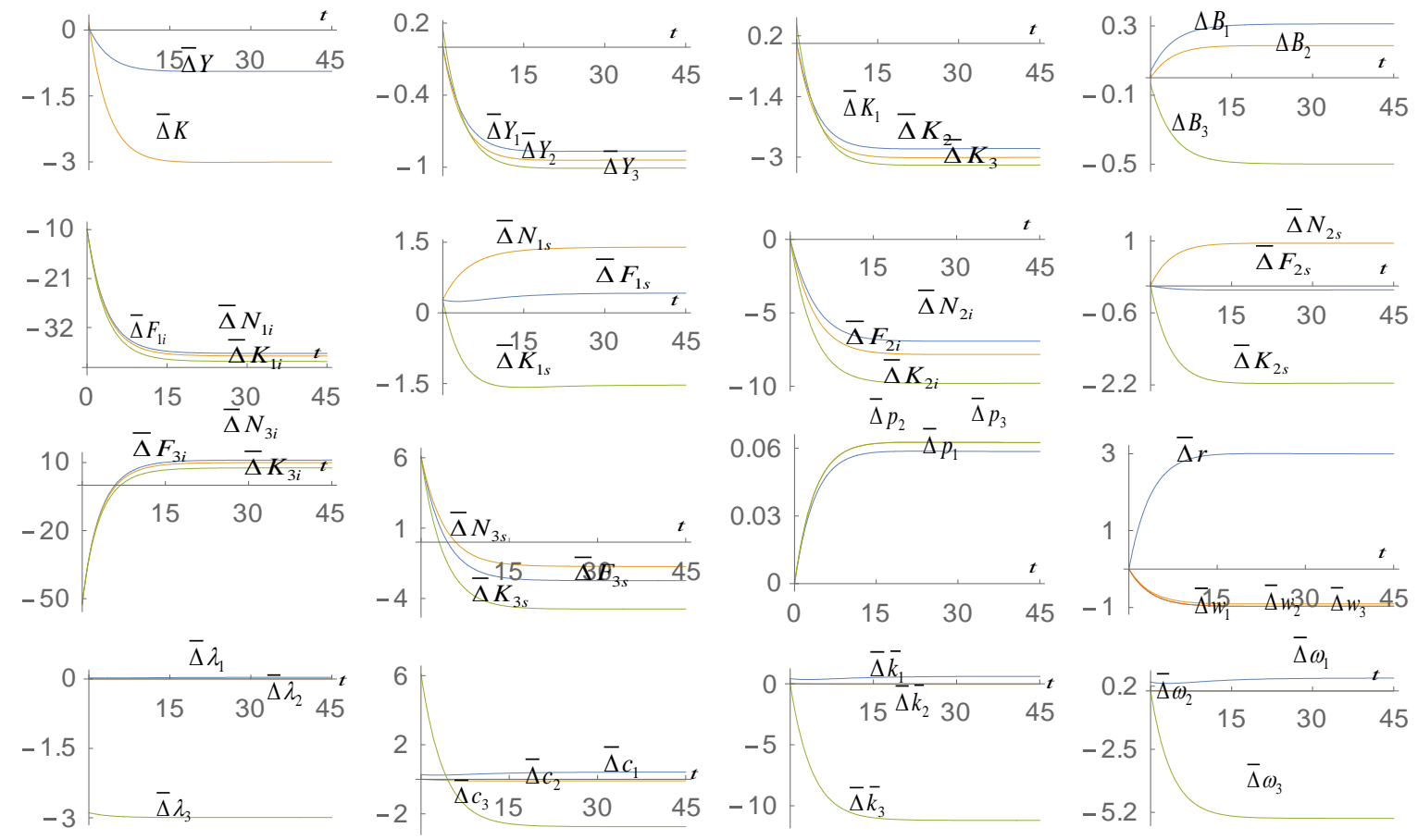

Figure 3. The Poor Country's Conspicuous Consumption Being Encouraged

\section{The rich country augmenting the propensity to save}

We now study the effects of the following change in the rich country's propensity to save: $\tilde{\lambda}_{10}: 0.8 \Rightarrow 0.81$. The simulation result is plotted in Figure 4. The global income, global wealth and each country's national income are enhanced. The wage rates in the three economies are increased and the rate of interest is reduced in tandem with rising global wealth. All the national economies use more capital inputs. The prices of services fall slightly in all the national economies. The middle and poor economies' trade balances are slightly deteriorated and the rich economy' trade balance is improved. As illustrated in the figure there are also economic structural changes in the three economies. The social status, 
consumption level and wealth of the rich are all increased. The social status, consumption level and wealth of the middle and poor are slightly affected. We see that a rise in the rich's propensity to save augments the global income and wealth and enlarges the inequality gaps between the rich and poor.
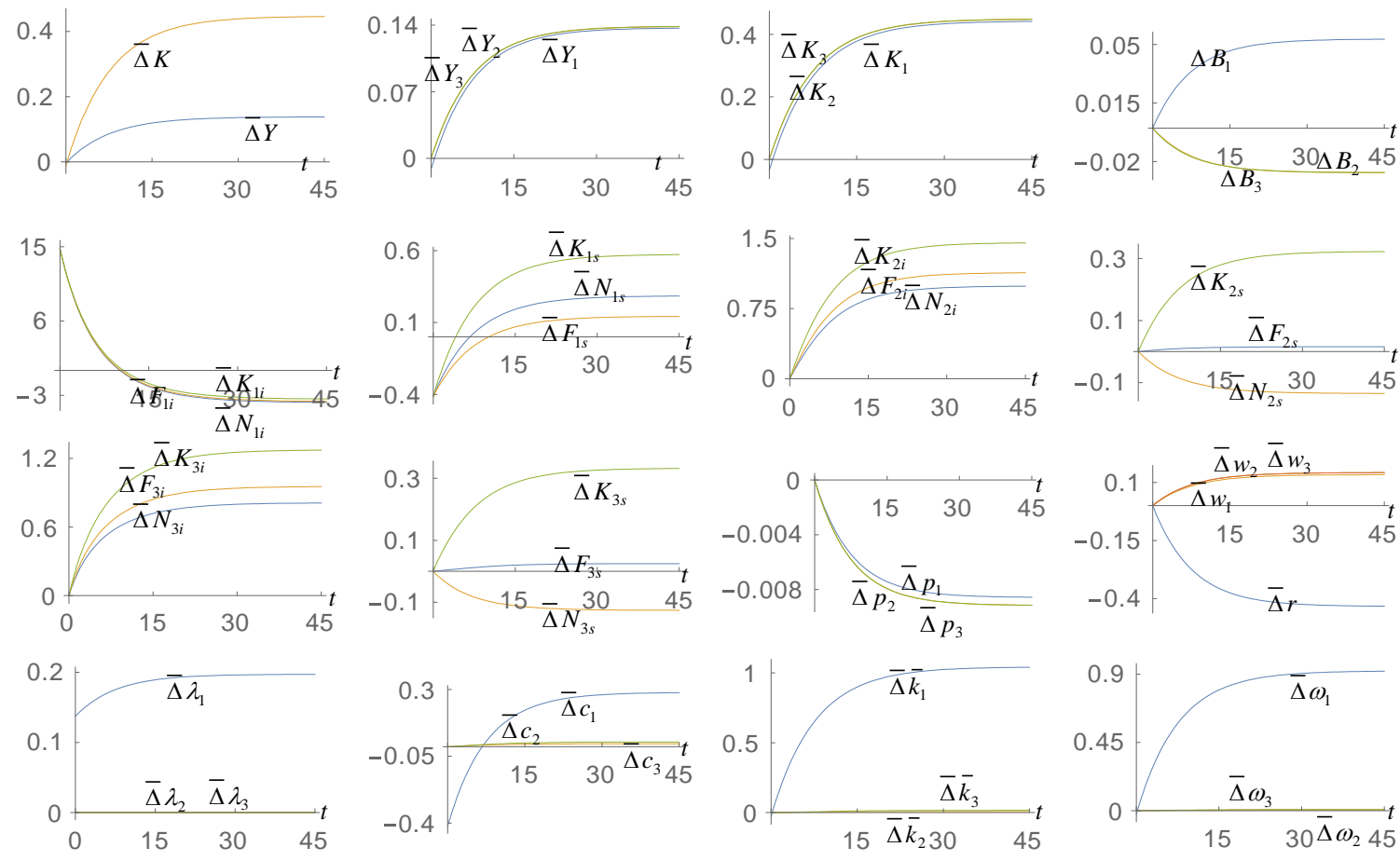

Figure 4. The Rich Country Augmenting the Propensity to Save

\section{A population expansion in the poor country}

We now examine the effects of the following change in the poor economy's population $N_{3}: 30 \Rightarrow 32$. The simulation result is plotted in Figure 5. As the poor country has more population, the global wealth and income are increased. The wage rates are reduced and the rate of interest is enhanced. The prices of services are slightly raised in the three economies. The poor economy augments its national income and the other two economies' national incomes are slightly reduced. The poor country's trade balance is deteriorated and the other two economies' trade balances are improved. Different sectors are also affected differently. The poor economy employs more capital input and the other two economies use less capital inputs. The poor economy's two sectors produce more and employ more two input factors. The other two national economies' capital goods sectors produce less and employ less two input factors. The consumer goods sector of the middle economy produces less and the consumer goods sector of the rich economy produces more. The rich's social status, propensity to save, consumption level and wealth are enhanced. The poor's and middle's social statuses, propensities to save, consumption levels and wealth levels are slightly affected. We see that more population in the poor economy lessens the inequality gaps in the national incomes between the rich and poor but enlarges per household income and wealth gaps between the rich and the poor. 

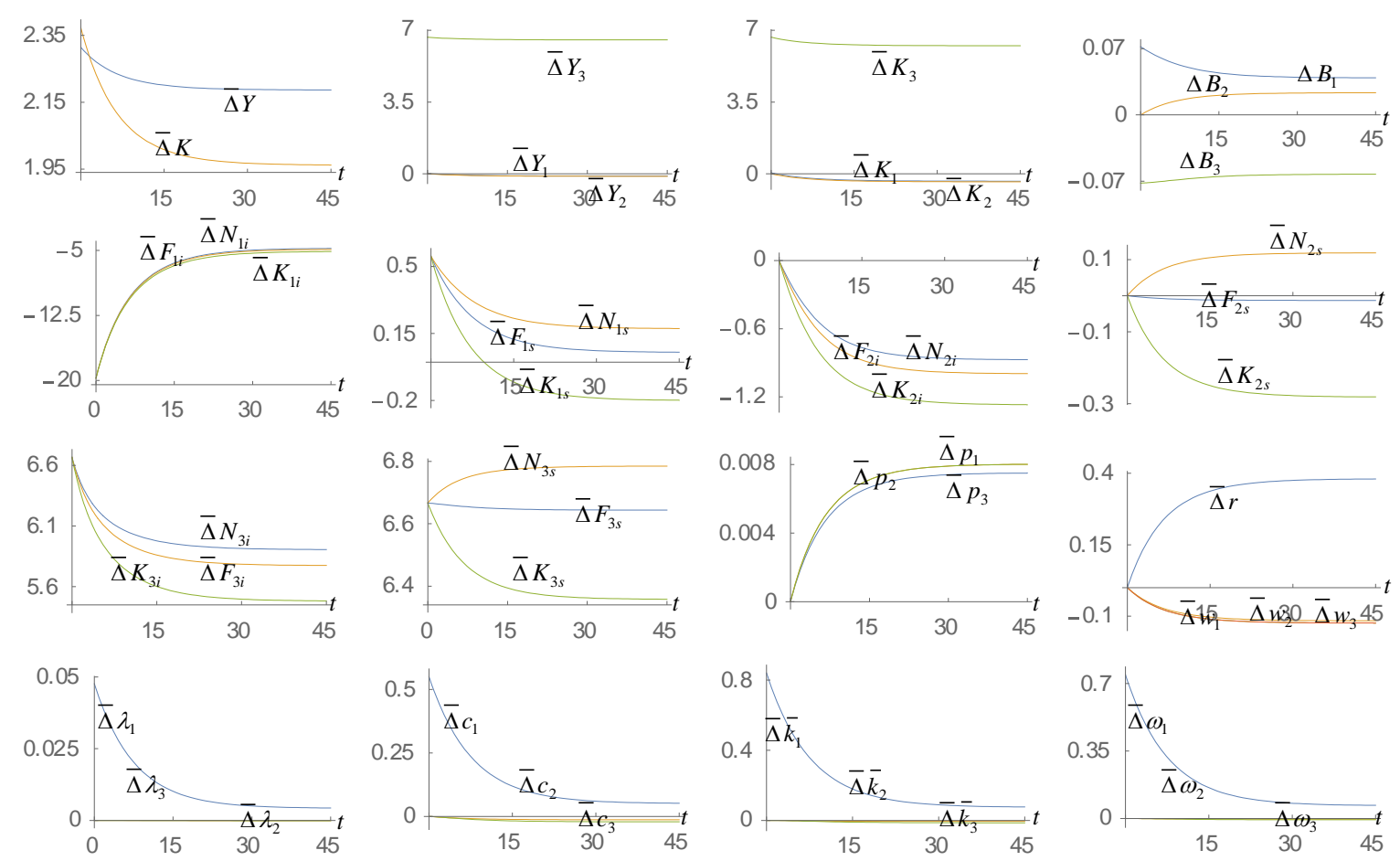

Figure 5. A Population Expansion in the Poor Country

\section{A rise in the poor country's depreciation rate of physical capital}

We now examine the effects of the following change in the poor economy's depreciation rate of physical capital $\delta_{3 k}: 0.04 \Rightarrow 0.05$. The simulation result is plotted in Figure 6. The global wealth and income are reduced. The poor economy's national income is reduced and the other two economies' national incomes are increased. The poor country's trade balance is improved and the other two economies' trade balances are deteriorated. The poor economy employs less capital input and the other two economies use more capital inputs. The wage rates in the rich and middle economies are enhanced and the rate of interest and wage rate in the poor economy are reduced. The price of consumer goods in the poor economy is increased and prices of consumer goods in the rich and middle economies are reduced. As illustrated in Figure 6, different sectors are also affected differently. The middle's social status, propensity to save, consumption level and wealth are slightly affected. The poor's and rich's social statuses, propensities to save, consumption levels and wealth levels are reduced. 

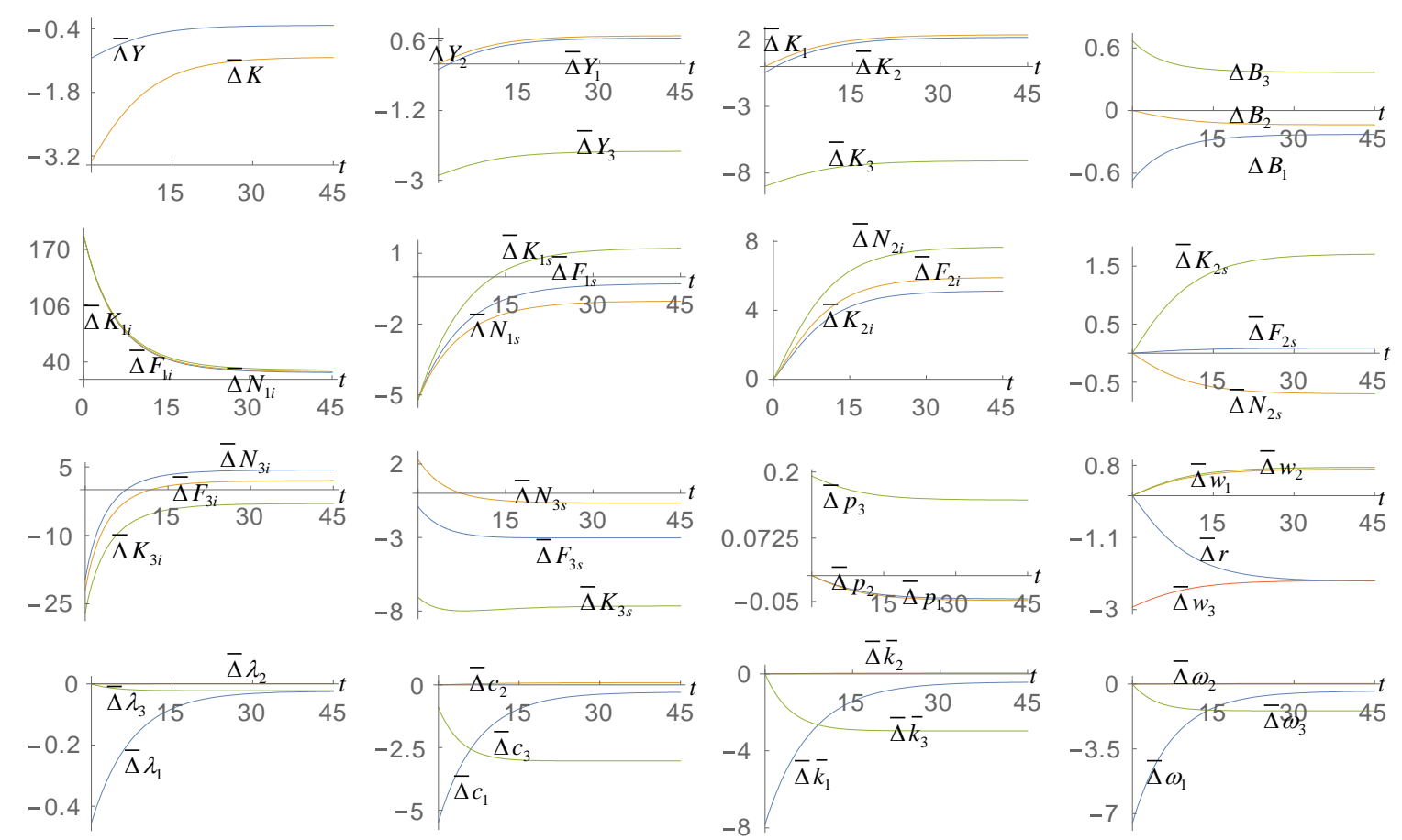

Figure 6. A Rise in the Poor Country's Depreciation Rate of Physical Capital

\section{The capital goods sector's total factor productivity in the rich economy being enhanced}

We now examine the effects of the following technological improvement in the rich economy's capital goods sector $A_{1 i}: 1.7 \Rightarrow 1.72$. The simulation result is plotted in Figure 7 .

The global wealth and income are increased. The rich country's national income and capital stocks employed is increased. The economic structural change is illustrated in the figure. The middle and poor economies' national incomes and capital stocks employed are lowered initially and augmented in the long term. The rate of interest is increased initially and reduced in the long term. The rich country's wage rate is enhanced. The middle and poor economies' wage rates are reduced initially and enhanced in the long term. The price of services in the rich economy is increased and the prices of services in the other two economies are slightly affected. The rich's social status, propensity to save, consumption level and wealth are initially reduced and the variables are enhanced in the long term. The poor's and middle's social statuses, propensities to save, consumption levels and wealth levels are slightly affected. We see that in the long term a technological improvement in the rich economy enlarges the inequality gaps in the national incomes between the rich and poor as well as enlarges per household income and wealth gaps between the rich and the poor. 

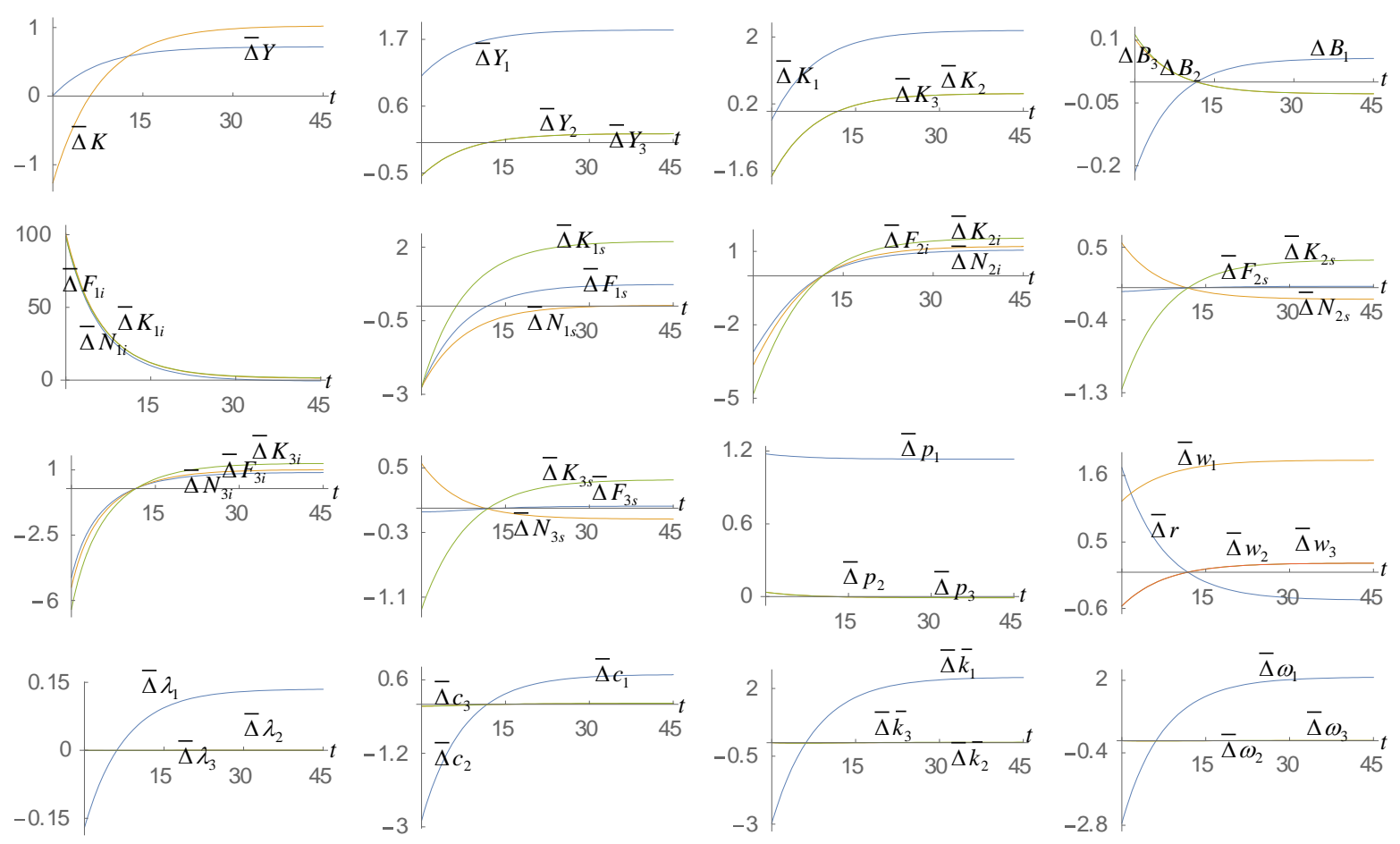

Figure 7. The Capital Goods Sector's Total Factor Productivity Being Enhanced

\section{Conclusions}

This paper examined the roles of social status, conspicuous consumption, and spirit of capitalism in global economic growth, trade patterns, and inequalities in income and wealth between countries. We constructed a multi-country growth model with endogenous physical capital, wealth accumulation and social status. The modelling of social status is influenced by the ideas related to economic growth and social status in the literature of economic growth. The economic system is built on the basis of the Solow model (Solow, 1956), the Uzawa two-sector model (Uzawa, 1961), and the Oniki-Uzawa trade model (Oniki and Uzawa, 1965). The global economic system consists of any number of countries and each country has one capital goods sector and one consumer goods sector. Different from most of the growth models with social status which use the Ramsey approach to household behavior, this study applies an alternative utility function proposed by Zhang $(1993$, 2009) to determine household behavior. The countries differ in preferences, spirits of capitalisms, and productivities in capital goods production, and consumer goods production. We show that the dynamics of $J$-country world economy is described by $J$ differential equations. We simulated the motion of the model with three countries and carried out comparative dynamic analysis with regard to some parameters. We comprehensively discussed some issues related to global growth and social status in the unique manner. It is important to further analyze behavior of the model with other forms of production or utility functions. As our analytical framework is quite general, it is possible to generalize and extend the model in different aspects. We may, for instance, introduce taxation into our general dynamic equilibrium model (e.g., Ng, 1987; Ireland, 1994, 1998; Bagwell and Bernheim, 1996; Corneo and Jeanne, 1997; and Rege, 2008). 


\section{Acknowledgement}

The author is grateful to the constructive comments of the two anonymous referees. The author is also grateful for the financial support from the Grants-in-Aid for Scientific Research (C), Project No. 25380246, Japan Society for the Promotion of Science.

\section{References}

Abel, A., Bernanke, B. S., \& Croushore, D. (2007). Macroeconomics. New Jersey: Prentice Hall. Azariadis, C. (1993). Intertemporal macroeconomics. Oxford: Blackwell.

Bagwell, L. S., \& Bernheim, D. B. (1996). Veblen effects in a theory of conspicuous consumption. American Economic Review, 86, 349-73.

Bakshi, G. S., \& Chen, Z. (1996). The Spirit of Capitalism and Stock-Market Prices. American Economic Review, 86, 133-57.

Barro, R. J., \& X. Sala-i-Martin. (1995). Economic growth. New York: McGraw-Hill, Inc.

Bernanke, B. S., \& Gurkaynak, R. S. (2001). Is growth exogenous? Taking Mankiw, Romer and Weil seriously. NBER Working Paper, No. 8365. http://dx.doi.org/10.1086/654431

Brecher, R. A., Chen, Z. Q., \& Choudhri, E. U. (2002). Absolute and comparative advantage, reconsidered: The pattern of international trade with optimal saving. Review of International Economics, 10, 645-56. http://dx.doi.org/10.1111/1467-9396.t01-1-00355

Burmeister, E., \& Dobell, A. R. (1970). Mathematical theories of economic growth. London: Collier Macmillan Publishers.

Chang, W.-Y. (2006). Relative wealth, consumption taxation, and economic growth. Journal of Economics, 88, 103-29. http://dx.doi.org/10.1007/s00712-006-0185-7

Chang, W. Y., \& Tsai, F. H. (2003). Money, social status, and capital accumulation in a cash-in-advance model: a comment. Journal of Money, Credit, and Banking, 33, 657-61. http://dx.doi.org/10.1353/mcb.2003.0027

Chang, W. Y., Tsai, H. F., \& Lai, C. C. (2004). Taxation, growth, and the spirit of capitalism. European Journal of Political Economy, 20, 1011-25. http://dx.doi.org/10.1016/j.ejpoleco.2003.07.001

Chen, H. J., \& Guo, J. T. (2009). Social status and the growth effect of money. Japanese Economic Review, 60, 133-41. http://dx.doi.org/10.1111/j.1468-5876.2008.00460.x

Chen, H. J., \& Guo, J. T. (2011). Money, social status and endogenous growth in a generalized cash-in-advance model. Pacific Economic Review, 16, 267-87. http://dx.doi.org/10.1111/j.1468-0106.2011.00547.x

Clemens, C. (2004). Status, risk-taking and intertemporal substitution in an endogenous growth model. Journal of Economics, $2, \quad$ 103-23. http://dx.doi.org/10.1007/s00712-004-0079-5 


\section{Macrothink}

Business and Economic Research ISSN 2162-4860 2016, Vol. 6, No. 1

Cole, H. L., Mailath, G. J., \& Postlewaite, A. (1992). Social norms, savings behavior, and growth. Journal of Political Economy, 100, 1092-25. http://dx.doi.org/10.1086/261855

Corneo, G., \& Jeanne, O. (1997). On relative wealth effects and the optimality of growth. Economics Letters, 54, 87-92. http://dx.doi.org/10.1016/S0165-1765(96)00940-8

Corneo, G., \& Jeanne, O. (1997a). Status, the Distribution of wealth, and growth. Discussion paper A-561, University of Bonn.

Corneo, G., \& Jeanne, O. (1999). Social organization in an endogenous growth model. International Economic Review, 40, 711-25. http://dx.doi.org/10.1111/1468-2354.00036

Corneo, G., \& Jeanne, O. (2001). On relative wealth effects and long-run growth. Research in Economics, 55, 349-58. http://dx.doi.org/10.1006/reec.2001.0260

Deardorff, A. V., \& Hanson, J. A. (1978). Accumulation and a long-run heckscher-ohlin theorem. Economic Inquiry, 16, 288-92. http://dx.doi.org/10.1111/j.1465-7295.1978.tb00288.x

Duesenberry, J. (1949). Income, saving and the theory of consumer behavior. Cambridge: Harvard University Press.

Fang, H. (2001). Social culture and economic performance. American Economic Review, 91, 924-37. http://dx.doi.org/10.1257/aer.91.4.924

Fershtman, C., Murphy, K. M., \& Weiss, Y. (1996). Social status, education and growth. Journal of Political Economy, 106, 108-32. http://dx.doi.org/10.1086/262019

Fisher, W. H., \& Hof, F. X. (2005). Status seeking in the small open economy. Journal of Macroeconomics, 27, 209-32. http://dx.doi.org/10.1016/j.jmacro.2004.01.001

Frank, R. (1985). The demand for non-observable and other non-positional goods. American Economic Review, 75, 101-16.

Fraumeni, B. M. (1997). The measurement of depreciation in the U.S. national income and product accounts. Survey of Current Business, 77, 7-23.

Hall, B. H. (2007). Measuring the returns to R\&D: The depreciation problem. NBER Working Paper, No. 13473.

Ikeda, S., \& Ono, Y. (1992). Macroeconomic dynamics in a multi-country economy - A dynamic optimization approach. International Economic Review, 33, 629-644. http://dx.doi.org/10.2307/2527130

Ireland, N. J. (1994). On limiting the market for status signals. Journal of Public Economics, 53, 91-110. http://dx.doi.org/10.1016/0047-2727(94)90015-9

Ireland, N. J. (1998). Status-seeking, income taxation and efficiency. Journal of Public Economics, 70, 99-113. http://dx.doi.org/10.1016/S0047-2727(98)00062-0

Konrad, K. (1992). Wealth seeking reconsidered. Journal of Economic Behavior and Organization, 18, 215-27. http://dx.doi.org/10.1016/0167-2681(92)90028-A 
Kurz, M. (1968). Optimal Economic Growth and Wealth Effects. International Economic Review, 9, 348-57. http://dx.doi.org/10.2307/2556231

Miles, D., \& Scott, A. (2005). Macroeconomics - Understanding the wealth of nations. Chichester: John Wiley \& Sons, Ltd.

Nadiri, M. I., \& Prucha, I. R. (1993). Estimation of the depreciation rate of physical and R\&D Capital in the U.S. total manufacturing sector. MBER Working Paper, No. 4591.

Ng, Y. K. (1987). Diamonds are a government's best friend: Burden-free taxes on goods valued for their values. American Economic Review, 77, 186-91.

Nishimura, K., \& Shimomura, K. (2002). Trade and indeterminacy in a dynamic general equilibrium model. Journal of Economic Theory, 105, 244-60. http://dx.doi.org/10.1006/jeth.2001.2892

Oniki, H., \& Uzawa, H. (1965). Patterns of trade and investment in a dynamic model of international trade. Review of Economic Studies, 32, 15-38. http://dx.doi.org/10.2307/2296328

Ono, Y., \& Shibata, A. (2005). Fiscal spending, relative-price dynamics, and welfare in a world economy. Review of International Economics, 13, 216-36. http://dx.doi.org/10.1111/j.1467-9396.2005.00500.x

Rauscher, M. (1997). Conspicuous consumption, economic growth, and taxation. Journal of Economics, 66, 35-42. http://dx.doi.org/10.1007/BF01231466

Rege, M. (2008). Why do people care about social status? Journal of Economic Behavior \& Organization, 66, 233-42. http://dx.doi.org/10.1016/j.jebo.2006.04.005

Solow, R. (1956). A contribution to the theory of growth. Quarterly Journal of Economics, 70, 65-94. http://dx.doi.org/10.2307/1884513

Uzawa, H. (1961). On a two-sector model of economic growth. Review of Economic Studies, 29, 47-70. http://dx.doi.org/10.2307/2296180

Veblen, T. (1899). The theory of the leisure class. New York: Modern Library.

Zhang, W. B. (1993). Woman's labor participation and economic growth - Creativity, knowledge utilization and family preference. Economics Letters, 42, 105-10. http://dx.doi.org/10.1016/0165-1765(93)90181-B

Zhang, W. B. (1994). A multi-country free trade model with capital accumulation. International Economic Journal, 8, 53-66. http://dx.doi.org/10.1080/10168739400080005

Zhang, W. B. (2005). Economic growth theory. Hampshire: Ashgate.

Zhang, W. B. (2009). Monetary growth theory: money, interest, prices, capital, knowledge, and economic structure over time and space. London: Routledge.

Zhang, W.B. (2012). Global economic growth, trade patterns and non-tradable services. Global Business \& Economics Anthology, 1, 296-306. 
Zhang, W. B. (2015). How do the richest $1 \%$ own $50 \%$ of global wealth in an integrated walrasin-general-equilibrium and Oniki-Uzawa's trade theory. Journal of Academic Research in Economics, 7, 7-44.

Zou, H. F. (1994). The spirit of capitalism and long-run growth. European Journal of Political Economy, 10, 279-93. http://dx.doi.org/10.1016/0176-2680(94)90020-5

Zou, H. F. (1995). The spirit of capitalism and savings behavior. Journal of Economic Behavior and Organization, 28, 131-43. http://dx.doi.org/10.1016/0167-2681(95)00024-2

\section{Appendix}

Proving the Lemma

By (2) and (4), we obtain

$$
z_{j} \equiv \frac{r+\delta_{j k}}{w_{j}}=\frac{N_{j m}}{\bar{\beta}_{j m} K_{j m}}, \quad j=1, \ldots, J, m=i, s
$$

where $\bar{\beta}_{j m} \equiv \beta_{j m} / \alpha_{j m}$. Insert (A1) in (2)

$$
r=\alpha_{j r} z_{j}^{\beta_{j i}}-\delta_{j k}, w_{j}=\alpha_{j} z_{j}^{-\alpha_{j i}}
$$

where

$$
\alpha_{j r}=\alpha_{j i} \bar{\beta}_{j i}^{\beta_{j i}} A_{j i}, \quad \alpha_{j}=\frac{\beta_{j i} A_{j i}}{\bar{\beta}_{j i}^{\alpha_{j i}}}
$$

From (A2) we have

$$
r=\alpha_{j r} z_{j}^{\beta_{j i}}-\delta_{j k}=\alpha_{1 r} z_{1}^{\beta_{1 i}}-\delta_{1 k}, \quad j=1, \ldots ., J
$$

From the above equations we solve

$$
z_{j}\left(z_{1}\right)=\left(\frac{\alpha_{1 r} z_{1}^{\beta_{1 i}}+\delta_{j k}-\delta_{1 k}}{\alpha_{j r}}\right)^{1 / \beta_{j i}}, j=2, \ldots ., J .
$$

Hence, we determine $r, w_{j}$, and $z_{j}$, as functions of $z_{1}$. From (3) and (4), we have

$$
p_{j}\left(z_{1}\right)=\frac{\bar{\beta}_{j s}^{\alpha_{j s}} z_{j}^{\alpha_{j s}} w_{j}}{\beta_{j s} A_{j s}} .
$$


From (A4) and the definitions of $\hat{y}_{j}$, we have

$$
\hat{y}_{j}=(1+r) \bar{k}_{j}+w_{j} .
$$

Insert $p_{j} c_{j}=\xi_{j} \hat{y}_{j}$ in (15)

$$
\xi_{j} N_{j} \hat{y}_{j}=p_{j} F_{j s} .
$$

Substituting (A5) in (A6) yields

$$
N_{j s}=g_{j} \xi_{j} \bar{k}_{j}+\xi_{j} \bar{g}_{j}
$$

where we use $w_{j} N_{j s}=\beta_{j s} p_{j} F_{j s}$ and

$$
g_{j}\left(z_{1}\right) \equiv\left(\frac{1+r}{w_{j}}\right) \beta_{j s} N_{j}, \quad \bar{g}_{j} \equiv \beta_{j s} N_{j}
$$

From (11) and (A7)

$$
N_{j i}=N_{j}-N_{j s} .
$$

From (A1) and (16), we get

$$
\frac{N_{j i}}{z_{j} \bar{\beta}_{j i}}+\frac{N_{j s}}{z_{j} \bar{\beta}_{j s}}=K_{j} .
$$

Insert (A8) in (A9)

$$
\bar{\beta}_{j} N_{j s}=K_{j}-\bar{f}_{j},
$$

where

$$
\bar{f}_{j} \equiv \frac{N_{j}}{z_{j} \bar{\beta}_{j i}}, \bar{\beta}_{j} \equiv\left(\frac{1}{\bar{\beta}_{j s}}-\frac{1}{\bar{\beta}_{j i}}\right) \frac{1}{z_{j}} .
$$

From (A10) and (A7), we get

$$
\bar{\beta}_{1} g_{1} \xi_{1} \bar{k}_{1}+\xi_{1} \bar{\beta}_{1} \bar{g}_{1}=K-\bar{f}_{0},
$$

where 


$$
\bar{f}_{0} \equiv \sum_{j=1}^{J} \bar{f}_{j}+\sum_{j=2}^{J} \bar{\beta}_{j} N_{j s}
$$

Insert $K=\sum_{j=1}^{J} \bar{k}_{j} \bar{N}_{j}$ in (A11)

$$
\left(W \bar{k}_{1}+h_{1}\right) \xi_{1}-\bar{k}_{1}=\bar{W}
$$

where

$$
W \equiv \frac{\bar{\beta}_{1} g_{1}}{N_{1}}, \quad h_{1} \equiv \frac{\bar{\beta}_{1} \bar{g}_{1}}{N_{1}}, \bar{W}\left(z_{1},\left\{\bar{k}_{j}\right\}\right) \equiv\left(\sum_{j=2}^{J} \bar{k}_{j} N_{j}-\bar{f}_{0}\right) \frac{1}{N_{1}}
$$

From the definitions of $\xi_{j}$, (6) and (8), we have

$$
\xi_{j}=\frac{\bar{\omega}_{j 0}+\bar{k}_{j}}{\widetilde{\omega}_{j 0}+\hat{\omega}_{j 0} \bar{k}_{j}}
$$

where

$$
\bar{\omega}_{j 0} \equiv \frac{\bar{\xi}_{j 0}+\tilde{\xi}_{j 0} \omega_{j 0}}{\tilde{\xi}_{j 0} \omega_{j L}}, \quad \tilde{\omega}_{j 0} \equiv \frac{\bar{\xi}_{j 0}+\bar{\lambda}_{j 0}+\left(\tilde{\xi}_{j 0}+\tilde{\lambda}_{j 0}\right) \omega_{j 0}}{\tilde{\xi}_{j 0} \omega_{j L}}, \quad \hat{\omega}_{j 0} \equiv \frac{\tilde{\xi}_{j 0}+\tilde{\lambda}_{j 0}}{\tilde{\xi}_{j 0}}
$$

Insert (A13) for the case of $j=1$ in (A12)

$$
\bar{k}_{1}^{2}+f \bar{k}_{1}+f_{0}=0,
$$

where

$$
f\left(z_{1},\left\{\bar{k}_{j}\right\}\right) \equiv \frac{\bar{\omega}_{10} W+h_{1}-\tilde{\omega}_{10}-\hat{\omega}_{10} \bar{W}}{W-\hat{\omega}_{10}}, f_{0}\left(z_{1},\left\{\bar{k}_{j}\right\}\right) \equiv \frac{\bar{\omega}_{10} h_{1}-\bar{W} \tilde{\omega}_{10}}{W-\hat{\omega}_{10}}
$$

Solve (A14)

$$
\bar{k}_{1}=\phi\left(z_{1},\left\{\bar{k}_{j}\right\}\right)=-\frac{f}{2} \pm \sqrt{\frac{f^{2}}{4}-f_{0}} .
$$

The problem has two solutions. We will determine meaningful solutions by simulation. In our simulation there is a unique meaningful solution given by 


$$
\bar{k}_{1}=\phi\left(z_{1},\left\{\bar{k}_{j}\right\}\right)=-\frac{f}{2}+\sqrt{\frac{f^{2}}{4}-f_{0}} .
$$

It is straightforward to confirm that all the variables can be expressed as functions of $z_{1}$ and $\left\{\bar{k}_{j}\right\}$ by the following procedure: $r$ and $w_{j}$ by (A2) $\rightarrow z_{j}$ by (A3) $\rightarrow \bar{k}_{1}$ by (A15) $\rightarrow$ $\xi_{j}$ by $(\mathrm{A} 13) \rightarrow N_{j s}$ by $(\mathrm{A} 7) \rightarrow N_{j i}$ by $(\mathrm{A} 8) \rightarrow \hat{y}_{j}$ by (A5) $\rightarrow K_{j s}$ and $K_{j i}$ by (A1) $\rightarrow \quad F_{j i}$ and $F_{j s}$ by the definitions $\rightarrow p_{j}$ by (A4) $\rightarrow c_{j}$ and $s_{j}$ by (13) $\rightarrow$ $K_{j}=K_{j i}+K_{j s}$. From this procedure and (12), we have

$$
\begin{gathered}
\dot{\bar{k}}_{1}=\Lambda_{0}\left(z,\left\{\bar{k}_{j}\right\}\right) \equiv \lambda_{1} \hat{y}_{1}-\bar{k}_{1}, \\
\dot{\bar{k}}_{j}=\Lambda_{j}\left(z,\left\{\bar{k}_{j}\right\}\right) \equiv \lambda_{j} \hat{y}_{j}-\bar{k}_{j}, \quad j=2, \ldots, J .
\end{gathered}
$$

Taking derivatives of equation (A15) with respect to $t$ implies

$$
\dot{\overline{k_{1}}}=\frac{\partial \phi}{\partial z_{1}} \dot{z}_{1}+\sum_{j=2}^{J} \Lambda_{j} \frac{\partial \phi}{\partial \bar{k}_{j}}
$$

where we use (A17). In summary, we proved the lemma. Equal (A18) and (A16)

$$
\dot{z}_{1}=\Lambda_{1}\left(z_{1},\left\{\bar{k}_{j}\right\}\right) \equiv\left(\Lambda_{0}-\sum_{j=2}^{J} \Lambda_{j} \frac{\partial \phi}{\partial \bar{k}_{j}}\right)\left(\frac{\partial \phi}{\partial z_{1}}\right)^{-1} .
$$

\section{Copyright Disclaimer}

Copyright for this article is retained by the author(s), with first publication rights granted to the journal.

This is an open-access article distributed under the terms and conditions of the Creative Commons Attribution license (http://creativecommons.org/licenses/by/3.0/). 